\title{
Analysis of Deposits and Advances: Public Sector Commercial Banks in India
}

\section{Ashish Gupta}

** Dr.V.S. Sundram

Effulgence

Vol. 14 No. 1

January - June, 2016

Rukmini Devi Institute of Advanced Studies

E-mail : effulgence@rdias.ac.in, Website : www.rdias.ac.in

http:/ / effulgence.rdias.ac.in/user/default.aspx

https:/ /dx.doi.org/10.33601/effulgence.rdias/v14/i1/2016/57-66

\begin{abstract}
Bank is the one of the major stream in Indian financial system. The primary function of banks are lending and borrowing the money to needy group of people. Public sector banks have captured most of the part of share in Indian economy in comparisons to Pvt.SBs but PSBs bave not performedlexecuted their primary function (Advances and Deposits) in appropriate tactic, due to this advances and deposits consistently shown the fluctuating and decline trends and performed rather poorly over the last few decades. In this context the present paper attempts to study the deposits and advances generated by PSBs banks during a period of 10 year from 2005-2006 to 2014-2015. There are eight variables have been selected for the study. This study is primary based on secondary data and Kruskal -Wallis Test has been used to know the significant difference in the growth rates of deposit and advances of selected PSBs in India. The result shows that the growth rate of selected variables have less growth in all over the years on selected variable have been taken for the study.
\end{abstract}

Key Words: Public Sector Banks, Term Deposit, Saving Bank Deposits, Priority Sector.

\section{INTRODUCTION}

A dvances and deposits are one of the main functions of any commercial banks in India. An advance is a credit facility provided by the bank to its customers both individuals and institutions. Advances are normally granted for a short period of time. Further, the purpose of granting advances and the rate of interest charged on advances varies from bank to bank. The interest is charged only on the amount withdrawn and not on the sanctioned amount (Muraleedharan, 2009). On the other hand, Deposits are liability to all banks, which need money to lend. It is the amounts that pay citizen (resident or non-resident) keep with the bank subject to some regulatory compliance. In turn, banks pay interest on deposits. It is considered the safest form of investments. Deposits are of two type's current and saving deposits as well as term deposits. Growth in traditional deposit funding sources has stagnated at many banks in recent years and has largely failed to keep up with the growth in bank assets. In response to these trends, banks have had to supplement traditional funding sources with a verity of new, but potentially less stable and more expensive, funding instrument (www.ibef.org). This study is mainly focused on management of advances and deposits of selected PSBs and thus current performance of bank in this competitive era.

\section{STATEMENT OF PROBLEM}

Quickly by going through last few years trend of banking Sector, It has been observed that PSBs have not performed well up to the mark, which shows the low 
escalation of Indian banking system. Banking sector is struggling with the high level of non-performing assets, especially in public sector banks. Gross NPA ratio of the public sector banks increased to $5.43 \%$ at the end of March 2015 as compared to $4.72 \%$ a year ago and there is a decline in the growth rate of deposits, loans and advances in comparison to consecutive previous years respectively. So, in this paper we have to study and analyses the performance of advances and deposits of selected PSBs in India.

\section{REVIEW OF LITERATURE}

Ambalagan and Selvakumar (2014) in their article, "Analysis of Deposits and Advances of selected Private Sector Commercial banks", examined the deposits and Advances of Selected Tamil Nadu Private sector Banks. Their study covered a period of 11 years starting from 2001 to 2011 and Kruskal Wallis Test is used. The article concluded that there is no significant difference among the Demand Deposit, Saving bank Deposit, Term Deposit, Total Deposits, Priority sector Advances, Non Priority Sector advances and Total Advance of various TNBPvT.SCBs.

Sharma (2012) in his article, "Deposits and Advances: A Comparative analysis of Indian Commercial Banks" studied about the deposits and advances generated by Indian scheduled commercial banks during a period of 11 years from 2000 to 2010 . The analysis has been done through nine different ration concerning with cash, credit, investments and advance etc.

Kaur (2012) conducted a study on "An Empirical Study on the Performance Evaluation of Public Sector Banks in India" the researcher observed that interest income shows a fluctuating trend and growth rate of net profit of public sector sectors commercial banks fluctuated during the study (2001-2010) period.they found that there is a high positive correlation between the profitability and interest, profitability and operating expense and profitability and other income of PSBC in India.

Dhanabhakyam and Kavitha (2012) in his article "Financial Performance of Selected Public Sector Bank in India" stated that analyzed the performance of 6

Effulgence, Vol. 14, No.1, January - June 2016 public sector banks for the year 2001 to 2010. They used various statistical tools such as ratio analysis, correlation analysis, and regression analysis, to find out the objective. The Researchers found that the Indian banking system faces several difficulties and challenges.The selected public sector bank have performed well on the sources of growth rate and financial efficiency during the study period. But old private sector bank and new private sector bank play a vital role in marketing of new type of deposits and advances schemes.

Goeal and Rekhi (2013) in his article "A Comparatively Study on the Performance of Selected Public Sector and Private Sector Bank in India" stated that analyzed the performance of three public sector and private sector bank for the year 2009 to 2012. They used three set of ratio operating performance ratio, financial ratio, and efficiency ratio. In all ten ratios were used. They found that axis bank took the first position followed the ICICI, SBI, HDFC, PNB and BOB. Punjab National Bank return on equity is very high as compared to other banks and they have good association with deposit but there conversion of deposits into credits is very less and more need to work on it. ICICI bank has good association with CAR and deposits in bank s are very high and net interest margin is less which needs to be increased which will impact the profitability.

Jha and Sarangi (2011) evaluated the performance of seven public sector and private sector banks for the year 2009-10. They used three sets of ratios, operating performance ratios, financial ratios and efficiency ratios. They found that Axis bank took the first position and followed by ICICI Bank, PNB, BOI, SBI, IDBI AND HDFC bank, in that order.

\section{OBJECTIVES OF THE STUDY}

The study has the following objectives:

- To study the Deposit and Advances of selected public sector banks

- To compare the deposits and Advances of selected public sector banks. 


\section{HYPOTHESIS OF THE STUDY}

For the purpose of comparing the Deposits and Advances of Selected PSBs, the following NULL hypothesis was framed.

- There is no significant difference between deposits and advances of selected public sector banks during the study period

\section{RESEARCH METHODOLOGY DATA COLLECTION}

The study consists of five Public Sector banks namely Bank of Baroda, Canara Bank, Bank of India, Punjab National Bank and Central Bank of India. The data purely based on secondary and it has been collected from annual reports and officials records of banks.

\section{PERIOD OF STUDY}

This study covers the period of ten years starting from 2005-06 to 2014-2015

\section{STATISTICAL TOOLS USED}

KRUSKAL -WALLIS TEST is used, in order to know the significant difference in the growth rates of deposits and advances of Selected PSBs. It has been considered one of the appropriate methods to evaluate the selected factors by assign ranking on various factors.

\section{SCOPE OF THE STUDY}

Deposits and Advances of public sector bank have taken into consideration of inside and outside India.

\section{LIMITATION OF STUDY}

The study has some limitations and the same has been mentioned below:-

- The study is related to selected public sector banks only.

- The study consists to a period of ten year from 2005-6 to 2014-15 only.
- The study is based on Deposits and Advances of selected PSBs only.

\section{KRUSKAL -WALLIS TEST}

The Kruskal - Wallis Test is a non parametric test. Which means that is does not assume that the data come from a distribution that can be completely described by two parameters means and standard deviation The test does not require the data to be normal, but instead use the rank of the data values instead of the actual data values for the analysis. The Kruskal Wallis Test statistic is

$$
W=\frac{12}{N(N+1)} \sum_{\mathrm{i}=1}^{\mathbf{k}}\left(\frac{\mathrm{Ri}^{2}}{\mathrm{ni}}\right)-3(n+1)
$$

Where

$$
\mathrm{Ri}=\text { The sum of the ranks for group } \mathrm{i}
$$

$\mathrm{ni}=(1,2, \mathrm{k})$ represent the sample size for each of the $\mathrm{K}$ group (i.e., samples)

$\mathrm{N}=$ Total number of sample

In order to compute $\mathrm{W}$ value for this study, convert the measurement observation to their ranks. The lowest value gets the rank of 1 and next smallest value gets the rank of 2 and so on. Then put all the data on formula and calculate the value of W. According to Kruskal -Wallis test, when null hypothesis the populations are identical, the sampling distribution of $\mathrm{W}$ can be approximated by chi-square distribution with $\mathrm{k}-1$ degree of freedom. This approximation is generally acceptable if each of the sample sizes is greater or equal to 5.The calculated value of $\mathrm{W}$ is compared with the chi-square at 5 percent level of significance. If the calculated value of $\mathrm{W}$ is less than or equal to table value of chi-square, then null hypothesis is accepted and when value of $\mathrm{W}$ is more then to table value of chi-square, then null hypothesis is rejected. 
COMPARISION OF DEMAND DEPOSITS OF SELECTED PUBLIC SECTOR BANKS

TABLE-1 Ranking of Growth Rates of Demand Deposits of Selected Public Sector Bank

\begin{tabular}{|c|c|c|c|c|c|c|c|c|c|c|}
\hline \multirow[t]{2}{*}{ Year } & \multicolumn{2}{|c|}{ BOB } & \multicolumn{2}{|l|}{$\mathrm{CB}$} & \multicolumn{2}{|l|}{ PNB } & \multicolumn{2}{|l|}{$\mathrm{BOI}$} & \multicolumn{2}{|l|}{$\mathrm{CBI}$} \\
\hline & Growth Rate & Rank & Growth Rate & Rank & Growth Rate & Rank & Growth Rate & Rank & Growth Rate & Rank \\
\hline $2005-06$ & 21.94 & 34 & 14.57 & 27 & 34.15 & 47 & 21.45 & 33 & 24.31 & 38 \\
\hline $2006-07$ & 17.86 & 29 & 21.28 & 32 & -1.54 & 2 & 26.45 & 42 & 11.72 & 22 \\
\hline $2007-08$ & 18.44 & 30 & 6.49 & 17 & 8.05 & 20 & 33.17 & 45 & 17.3 & 28 \\
\hline $2008-09$ & 23.56 & 37 & 8.32 & 21 & 5.75 & 12 & 0.87 & 6 & 1.11 & 7 \\
\hline $2009-10$ & 30.95 & 44 & 28.06 & 43 & 26.06 & 40 & 26.27 & 41 & 49.04 & 49 \\
\hline 2010-11 & 22.25 & 35 & 33.25 & 46 & 13.16 & 25 & 6.19 & 14 & 2.39 & 8 \\
\hline 2011-12 & 25.11 & 39 & 60.48 & 50 & 6.09 & 13 & 6.46 & 16 & -17.83 & 1 \\
\hline $2012-13$ & 23.26 & 36 & 0.5 & 5 & 4.92 & 9 & 12.94 & 24 & 14.28 & 26 \\
\hline 2013-14 & 40.28 & 48 & 19.14 & 31 & 5.44 & 10 & 6.43 & 15 & 6.58 & 18 \\
\hline 2014-15 & 5.49 & 11 & 11.85 & 23 & 6.61 & 19 & -0.53 & 3 & -0.25 & 4 \\
\hline Average & 22.91 & & 20.39 & & 10.87 & & 13.67 & & 10.87 & \\
\hline Total & & 343 & & 295 & & 197 & & 239 & & 201 \\
\hline
\end{tabular}

Source: Calculated values from the Annual Report of respective banks (2005-06 to 2014-15)

Table 1 shows the last 10 years growth rates of demand deposits of selected public sector bank such as Bank of Baroda (BOB), Canara Bank (CB), Punjab National Bank (PNB), Bank of India (BOI), and Central bank of India. It has been found that growth rates of demand deposit of all banks was much better in 2005 -06 in compared to 2014-15 except the Canara bank. The average growth rate of BOB has highest and PNB \& CBI has lowest in compared to others. In order to ascertain statistical significant difference in the growth rate of demand deposit of among the selected PSBs, on the basis of $\mathrm{H}$ test (KRUSKAL-WALLIS) the 'W' value has been calculated as:

$$
\begin{aligned}
& W=\frac{12}{\mathbf{5 0}(51)}\left|\frac{\mathbf{3 1 2}^{2}}{10}+\frac{226^{2}}{10}+\frac{224^{2}}{10}+\frac{\mathbf{3 0 3}^{2}}{10}+\frac{\mathbf{2 0 6}^{2}}{10}\right|-\mathbf{3}(\mathbf{5 1}) \\
& W=\frac{12}{2550}(11764.9+8702.5+3880.9+5712.1+4040.1)-153
\end{aligned}
$$

$$
\mathrm{W}=7.47
$$

COMPARISION OF SAVING BANK DEPOSITS OF SELECTED PUBLIC SECTOR BANKS

TABLE-2 Ranking of Growth Rates of Saving Bank Deposits of Selected Public Sector Banks

\begin{tabular}{|l|l|l|l|l|l|l|l|l|l|l|}
\hline \multirow{2}{*}{ Year } & \multicolumn{2}{|c|}{ BOB } & \multicolumn{2}{c|}{ CANARA } & \multicolumn{2}{c|}{ PNB } & \multicolumn{2}{c|}{ CBI } \\
\cline { 2 - 9 } & Growth Rate & Rank & Growth Rate & Rank & Growth Rate & Rank & Growth Rate & Rank & Growth Rate & Rank \\
\hline $2005-06$ & 19.24 & 39 & 20.51 & 43 & 18.58 & 37 & 20.61 & 44 & 15.51 & 28 \\
$2006-07$ & 16.26 & 31 & 13.3 & 18 & 14.75 & 26 & 14.79 & 27 & 12.06 & 10 \\
$2007-08$ & 13.3 & 19 & 8.73 & 2 & 11.81 & 9 & 14.3 & 23 & 13.51 & 20 \\
$2008-09$ & 18.76 & 38 & 18.55 & 36 & 16.5 & 32 & 14.22 & 21 & 12.77 & 13 \\
$2009-10$ & 23.67 & 48 & 19.29 & 40 & 24.72 & 49 & 25.87 & 50 & 21.03 & 45 \\
$2010-11$ & 22.67 & 46 & 17.53 & 35 & 19.65 & 41 & 22.92 & 47 & 17.05 & 34 \\
$2011-12$ & 15.71 & 29 & 10.53 & 6 & 13.02 & 14 & 13.11 & 16 & 10.39 & 5 \\
$2012-13$ & 13.04 & 15 & 9.84 & 4 & 16.86 & 33 & 16.12 & 30 & 12.35 & 11 \\
$2013-14$ & 14.39 & 24 & 20.19 & 42 & 14.5 & 25 & 13.18 & 17 & 12.49 & 12 \\
$2014-15$ & 14.24 & 22 & 9.53 & 3 & 6.24 & 1 & 10.57 & 7 & 11.04 & 8 \\
Average & 16.89 & & 14.16 & & 15.33 & & 16.12 & & 13.63 \\
Total & & 311 & & 229 & & 267 & & & \\
\end{tabular}

Source: Calculated values from the Annual Report of respective banks (2005-06 to 2014-15) 
Table 2 reveals the year wise growth rate of saving bank deposits of selected public sector banks had been fluctuating over the period from 2005 to 2014. It is found that average growth rate of BOB has highest and CBI has lowest in compared to other banks. The null hypothesis has been tested whether there is any statistically significant difference in the growth rates of saving bank deposits among the selected Public sector banks, on the basis of $\mathrm{H}$ test (KRUSKALWALLIS) and the 'W' value has been calculated as:

$$
\begin{gathered}
W=\frac{\mathbf{1 2}}{\mathbf{5 0}(\mathbf{5 1})} \boldsymbol{X}\left|\frac{\mathbf{3 1 1 ^ { 2 }}}{\mathbf{1 0}}+\frac{\mathbf{2 2 9 ^ { 2 }}}{\mathbf{1 0}}+\frac{\mathbf{2 6 7}^{2}}{\mathbf{1 0}}+\frac{\mathbf{2 8 2}^{2}}{\mathbf{1 0}}+\frac{\mathbf{1 8 6}^{2}}{\mathbf{1 0}}\right|-\mathbf{3}(\mathbf{5 1}) \\
W=\frac{12}{2550}(9672.1+5244.1+7128.9+7952.4+3459.6)-153 \\
W=4.44
\end{gathered}
$$

\begin{tabular}{|c|c|c|c|c|c|c|c|c|c|c|}
\hline \multirow[t]{2}{*}{ Year } & \multicolumn{2}{|c|}{$\mathrm{BOB}$} & \multicolumn{2}{|c|}{$\mathrm{CB}$} & \multicolumn{2}{|l|}{ PNB } & \multicolumn{2}{|l|}{ BOI } & \multicolumn{2}{|l|}{$\mathrm{CBI}$} \\
\hline & Growth Rate & Rank & Growth Rate & Rank & Growth Rate & Rank & Growth Rate & Rank & Growth Rate & Rank \\
\hline $2005-06$ & 12.45 & 11 & 21.58 & 26 & 10.29 & 9 & 18.31 & 21 & 3.17 & 2 \\
\hline $2006-07$ & 43.6 & 49 & 25.14 & 31 & 23.34 & 28 & 33.13 & 45 & 35.52 & 45 \\
\hline $2007-08$ & 25.28 & 33 & 8.26 & 7 & 19.02 & 22 & 28.11 & 39 & 46.97 & 50 \\
\hline $2008-09$ & 29.55 & 43 & 23.85 & 29 & 26.01 & 35 & 33.46 & 46 & 24.17 & 30 \\
\hline $2009-10$ & 25.19 & 32 & 27.28 & 37 & 14.95 & 15 & 19.34 & 23 & 21.48 & 25 \\
\hline $2010-11$ & 28.3 & 40 & 26.72 & 36 & 30.58 & 44 & 34.45 & 47 & 15.96 & 16 \\
\hline 2011-12 & 29.15 & 41 & 17.65 & 19 & 27.46 & 38 & 4.71 & 3 & 12.57 & 12 \\
\hline $2012-13$ & 25.79 & 34 & 9.03 & 8 & -2.95 & 1 & 21.65 & 27 & 16.47 & 17 \\
\hline $2013-14$ & 19.35 & 23 & 17.66 & 20 & 16.92 & 18 & 29.44 & 41 & 4.99 & 4 \\
\hline $2014-15$ & 7.62 & 6 & 13.5 & 13 & 14.03 & 14 & 12.45 & 11 & 5.31 & 5 \\
\hline Average & 24.63 & & 19.06 & & 17.96 & & 23.50 & & 18.66 & \\
\hline Total & & 312 & & 226 & & 224 & & 303 & & 206 \\
\hline
\end{tabular}

COMPARISION OF TERM DEPOSITS OF SELECTED PUBLIC SECTOR BANKS

TABLE-3 Ranking of Growth Rates of Term Deposits of Selected Public Sector Bank

Source: Calculated values from the Annual Report of respective banks (2005-06 to 2014-15)

Table 3 depicts the year wise growth rates of term deposits of PSBs. It is found that all selected banks had been fluctuating trend over the period from 2005 to 2014. PNB and CBI has shown increasing trend when we compared between two year 2005 and 2014. Average value of BOB has highest, it's followed by BOI and PNB has lowest average growth rate when compared to other banks. In order to ascertain statistical significant difference in the growth rate of term deposit of among the selected PSBs, on the basis of H test (KRUSKAL-WALLIS) the 'W' value has been calculated as:

$$
\begin{gathered}
\boldsymbol{W}=\frac{\mathbf{1 2}}{\mathbf{5 0}(\mathbf{5 1})}\left|\frac{\mathbf{3 4 3}^{2}}{\mathbf{1 0}}+\frac{\mathbf{2 9 5}^{2}}{\mathbf{1 0}}+\frac{\mathbf{1 9 7}^{2}}{\mathbf{1 0}}+\frac{\mathbf{2 3 9}^{2}}{\mathbf{1 0}}+\frac{\mathbf{2 0 1}^{2}}{\mathbf{1 0}}\right|-\mathbf{3}(\mathbf{5 1}) \\
W=\frac{12}{2550}(9734.4+5107.6+5017.6+9180.9+4243.6)-153 \\
W=3.63
\end{gathered}
$$


COMPARISION OF TOTAL DEPOSITS OF SELECTED PUBLIC SECTOR BANKS

TABLE-4 Ranking of Growth Rates of Total Deposits of Selected Public Sector Bank

\begin{tabular}{|c|c|c|c|c|c|c|c|c|c|c|}
\hline \multirow[t]{2}{*}{ Year } & \multicolumn{2}{|c|}{ ВОВ } & \multicolumn{2}{|c|}{ CANARA } & \multicolumn{2}{|l|}{ PNB } & \multicolumn{2}{|l|}{ BOI } & \multicolumn{2}{|l|}{ CBI } \\
\hline & Growth Rate & Rank & Growth Rate & Rank & Growth Rate & Rank & Growth Rate & Rank & Growth Rate & Rank \\
\hline $2005-06$ & 15.16 & 14 & 21.58 & 29 & 16.01 & 17 & 19.17 & 23 & 9.43 & 9 \\
\hline $2006-07$ & 33.37 & 49 & 21.9 & 31 & 16.85 & 18 & 27.63 & 46 & 24.51 & 34 \\
\hline $2007-08$ & 21.71 & 30 & 8.21 & 5 & 19.02 & 22 & 25.13 & 36 & 33.27 & 48 \\
\hline $2008-09$ & 26.55 & 44 & 21.3 & 27 & 26.01 & 41 & 26.46 & 43 & 18.99 & 21 \\
\hline $2009-10$ & 25.28 & 38 & 25.55 & 40 & 18.86 & 20 & 21.11 & 26 & 23.48 & 33 \\
\hline $2010-11$ & 26.6 & 45 & 25.28 & 37 & 25.5 & 39 & 30.08 & 47 & 75.65 & 50 \\
\hline 2011-12 & 26.01 & 41 & 11.46 & 11 & 21.31 & 28 & 6.47 & 4 & 9.38 & 8 \\
\hline $2012-13$ & 23.13 & 32 & 8.8 & 7 & 3.15 & 1 & 19.99 & 24 & 15.22 & 15 \\
\hline 2013-14 & 20.05 & 25 & 18.22 & 19 & 15.28 & 16 & 24.91 & 35 & 6.21 & 2 \\
\hline $2014-15$ & 8.55 & 6 & 12.63 & 13 & 11.07 & 10 & 11.52 & 12 & 6.46 & 3 \\
\hline Average & 22.64 & & 17.49 & & 17.30 & & 21.24 & & 22.26 & \\
\hline Total & & 324 & & 219 & & 212 & & 296 & & 223 \\
\hline
\end{tabular}

Source: Calculated values from the Annual Report of respective banks (2005-06 to 2014-15)

Table 4 illustrates the growth rate of total deposits of selected PSBs for the last ten years from 2005 to 2014. Growth rates of total deposits of selected bank have shown the fluctuating and decreasing trend over the period of study. In overall performance of PSBs, BOB has highest growth rate, it's followed by CBI \& BOI. And PNB has lowest average growth rate when compared to other banks. In order to ascertain statistical significant difference in the growth rate of total deposit of among the selected PSBs, on the basis of $\mathrm{H}$ test and the 'W' value has been calculated and the same has been mentioned below.

$$
\begin{gathered}
W=\frac{\mathbf{1 2}}{\mathbf{5 0}(\mathbf{5 1})}\left|\frac{\mathbf{3 2 4}^{2}}{\mathbf{1 0}}+\frac{\mathbf{2 1 9}^{2}}{\mathbf{1 0}}+\frac{\mathbf{2 1 2}^{2}}{\mathbf{1 0}}+\frac{\mathbf{2 9 6}^{2}}{\mathbf{1 0}}+\frac{\mathbf{2 2 3}^{2}}{\mathbf{1 0}}\right|-\mathbf{3}(\mathbf{5 1}) \\
\mathrm{W}=\frac{12}{2550}(10497.6+4796.1+4494.4+8761.6+4972.9)-153 \\
\mathrm{~W}=4.75
\end{gathered}
$$

\section{COMPARISION OF PRIORITY SECTOR ADVANCES OF SELECTED PUBLIC SECTOR BANKS}

TABLE-5 Ranking of Growth Rates of Priority Sector Advances of Selected Public Sector Bank

\begin{tabular}{|l|l|l|l|l|l|l|l|l|l|l|}
\hline \multirow{2}{*}{ Year } & \multicolumn{2}{|c|}{ BOB } & \multicolumn{2}{c|}{ CB } & \multicolumn{2}{c|}{ PNB } & CBI \\
\cline { 2 - 10 } & Growth & Rank & Growth & Rank & Growth & Rank & Growth & Rank & Growth & Rank \\
\hline $2005-06$ & 43.39 & 49 & 46.78 & 50 & 20.61 & 30 & 29.32 & 43 & 33.43 & 46 \\
$2006-07$ & 36.75 & 48 & 22.57 & 33 & 7.14 & 7 & 23.58 & 36 & 24.31 & 37 \\
$2007-08$ & 22.54 & 32 & 14.45 & 15 & 26.53 & 39 & 27.06 & 41 & 18.43 & 23 \\
$2008-09$ & 29.77 & 44 & 9.56 & 8 & 6.48 & 6 & 16.46 & 17 & 11.8 & 11 \\
$2009-10$ & 20.57 & 29 & 23.26 & 35 & 35.36 & 47 & 14.34 & 14 & 26.24 & 38 \\
$2010-11$ & 19.05 & 25 & 19.95 & 28 & 18.05 & 21 & 27.85 & 42 & 19.59 & 27 \\
$2011-12$ & 18.21 & 22 & 1.87 & 2 & 17.04 & 18 & 2.29 & 3 & 4.91 & 4 \\
$2012-13$ & 22.43 & 31 & 18.45 & 24 & 0.78 & 1 & 15.72 & 16 & 29.87 & 45 \\
$2013-14$ & 5.93 & 5 & 17.98 & 20 & 27.04 & 40 & 19.13 & 26 & 22.77 & 34 \\
$2014-15$ & 13.46 & 12 & 10.63 & 10 & 17.31 & 19 & 9.93 & 9 & 13.53 & 13 \\
Average & 23.21 & & 18.55 & & 17.63 & & 18.56 & & 13.53 \\
Total & & 297 & & 225 & & 228 & & \\
\hline
\end{tabular}

Source: Calculated values from the Annual Report of respective banks (2005-06 to 2014-15)

Table 5 depicts the growth rates of Priority Sector Advances of selected PSBs for the last ten years. Growth rates of 
Priority Sector of selected bank have shown the fluctuating and decreasing trend over the period of study. In 2005-06, where $\mathrm{BOB}, \mathrm{CB}, \mathrm{PNB}, \mathrm{BOI}$ and $\mathrm{CBI}$ invested in priority sector respectively $43.39 \%, 46.78 \%, 20.61 \%, 29.32 \%$, and $33.43 \%$ but in 2014-15, investment in priority sector of BOB, CB, PNB, BOI and CBI become low respectively $13.46 \%$, $10.63 \%, 17.31 \%, 9,93 \%$ and $13.53 \%$ when compared to $2005-06$. In overall performance of all ten year, BOB has highest average growth rate and CBI has lowest growth rate when compared to average growth rate of other banks. In order to ascertain statistical significant difference in the growth rate of Priority Sector Advances among the selected PSBs, $\mathrm{H}$ test (KRUSKAL-WALLIS) has been used and the 'W' value has been calculated as:

$$
\begin{gathered}
W=\frac{12}{\mathbf{5 0}(\mathbf{5 1})}\left|\frac{\mathbf{2 9 7 ^ { 2 }}}{\mathbf{1 0}}+\frac{\mathbf{2 2 5}^{2}}{\mathbf{1 0}}+\frac{\mathbf{2 2 8}^{2}}{\mathbf{1 0}}+\frac{\mathbf{2 4 7}^{2}}{\mathbf{1 0}}+\frac{\mathbf{2 7 8}^{2}}{\mathbf{1 0}}\right|-\mathbf{3}(\mathbf{5 1}) \\
W=\frac{12}{2550}(8820.9+5062.5+5198.4+6100.9+7728.4)-153 \\
W=1.87
\end{gathered}
$$

\begin{tabular}{|c|c|c|c|c|c|c|c|c|c|c|}
\hline \multirow[t]{2}{*}{ Year } & \multicolumn{2}{|c|}{$\mathrm{BOB}$} & \multicolumn{2}{|c|}{$\mathrm{CB}$} & \multicolumn{2}{|c|}{ PNB } & \multicolumn{2}{|c|}{ BOI } & \multicolumn{2}{|l|}{ CBI } \\
\hline & Growth & Rank & Growth & Rank & Growth & Rank & Growth & Rank & Growth & Rank \\
\hline $2005-06$ & 25.17 & 33 & 11.9 & 26 & -16.83 & 5 & -5.23 & 9 & 38.76 & 37 \\
\hline $2006-07$ & 33.76 & 37 & 20.84 & 30 & 122.21 & 49 & 12.63 & 27 & 31.62 & 36 \\
\hline 2007-08 & 86.22 & 47 & 41.22 & 40 & 2.94 & 21 & 5.03 & 22 & 58.35 & 43 \\
\hline 2008-09 & 65.2 & 44 & 282.78 & 50 & -11.19 & 6 & 38.65 & 38 & -20.07 & 3 \\
\hline $2009-10$ & -17.03 & 4 & -8.83 & 7 & 1.81 & 18 & 27.28 & 35 & -49.82 & 1 \\
\hline $2010-11$ & 24.33 & 32 & 81.98 & 46 & 53.94 & 41 & 10.58 & 25 & 93.03 & 48 \\
\hline 2011-12 & 2.82 & 19 & 2.89 & 20 & 26.67 & 34 & 0.59 & 15 & 1.09 & 16 \\
\hline 2012-13 & -4.92 & 10 & 15.83 & 28 & -5.68 & 8 & 78.28 & 45 & 24.29 & 31 \\
\hline 2013-14 & 1.58 & 17 & 9.22 & 24 & 16.3 & 29 & 58.26 & 43 & -4.77 & 11 \\
\hline 2014-15 & -1.8 & 12 & -0.48 & 13 & -22.23 & 2 & 5.49 & 23 & 0.25 & 14 \\
\hline Average & 21.53 & & 45.73 & & 16.79 & & 23.15 & & 17.27 & \\
\hline Total & & 255 & & 284 & & 213 & & 282 & & 240 \\
\hline
\end{tabular}

\section{COMPARISION OF ADVANCE IN PUBLIC SECTOR OF SELECTED PUBLIC SECTOR BANKS}

TABLE-6 Ranking of Growth Rates Advances in Public Sector of Selected Public Sector Bank

Source: Calculated values from the Annual Report of respective banks (2005-06 to 2014-15)

Table 6 shows the year wise growth rates of Priority Sector Advances of PSBs. Growth rates of advances PSBs have shown the fluctuating and decreasing trend over the period of study. It is found that average growth rate of CB has highest and PNB has lowest when compared to other banks. The null hypothesis has been framed whether there is any statistically significant difference in the growth rate of advances among the selected PSBs, on the basis of $\mathrm{H}$ test and 'W' value has been calculated as mentioned below.

$$
\begin{aligned}
\boldsymbol{W} & =\frac{\mathbf{1 2}}{\mathbf{5 0}(\mathbf{5 1})}\left|\frac{\mathbf{2 5 5}^{2}}{\mathbf{1 0}}+\frac{\mathbf{2 8 4}^{2}}{\mathbf{1 0}}+\frac{\mathbf{2 1 3}^{2}}{\mathbf{1 0}}+\frac{\mathbf{2 8 2}^{2}}{\mathbf{1 0}}+\frac{\mathbf{2 4 0}^{2}}{\mathbf{1 0}}\right|-\mathbf{3}(\mathbf{5 1}) \\
W & =\frac{12}{2550}(6202.5+8065.6+4535.9+7952.4+5760)-153 \\
W & =0.018
\end{aligned}
$$


COMPARISION OF ADVANCE IN INDIA SECTOR OF SELECTED PUBLIC SECTOR BANKS

TABLE-7 Ranking of Growth Rates of Advances in India of Selected Public Sector Bank

\begin{tabular}{|c|c|c|c|c|c|c|c|c|c|c|}
\hline \multirow[t]{2}{*}{ Year } & \multicolumn{2}{|c|}{ BOB } & \multicolumn{2}{|c|}{$\mathrm{CB}$} & \multicolumn{2}{|c|}{ PNB } & \multicolumn{2}{|c|}{ BOI } & \multicolumn{2}{|l|}{ CBI } \\
\hline & Growth & Rank & Growth & Rank & Growth & Rank & Growth & Rank & Growth & Rank \\
\hline $2005-06$ & 41.21 & 49 & 31.75 & 44 & 23.53 & 29 & 22.81 & 26 & 37.41 & 46 \\
\hline $2006-07$ & 71.46 & 50 & 23.95 & 31 & 29.44 & 43 & 28.99 & 41 & 38.18 & 47 \\
\hline $2007-08$ & 25.63 & 34 & 8.21 & 8 & 23.68 & 30 & 32.09 & 45 & 40.93 & 48 \\
\hline 2008-09 & 29.32 & 42 & 27.43 & 37 & 26.29 & 36 & 26.07 & 35 & 17.1 & 18 \\
\hline $2009-10$ & 21.28 & 23 & 20.5 & 22 & 19.06 & 20 & 16.67 & 17 & 23.27 & 28 \\
\hline 2010-11 & 28.68 & 39 & 24.35 & 33 & 27.6 & 38 & 22.44 & 25 & 23.09 & 27 \\
\hline 2011-12 & 19.28 & 21 & 10.36 & 11 & 18.68 & 19 & 8.23 & 9 & 13.71 & 14 \\
\hline $2012-13$ & 11 & 12 & 2.55 & 2 & 1.71 & 1 & 14.56 & 15 & 16.56 & 16 \\
\hline 2013-14 & 21.34 & 24 & 24.08 & 32 & 11.58 & 13 & 28.93 & 40 & 3.13 & 3 \\
\hline $2014-15$ & 7.24 & 6 & 9.05 & 10 & 6.25 & 4 & 8.19 & 7 & 6.29 & 5 \\
\hline Average & 27.64 & & 18.22 & & 18.78 & & 20.89 & & 21.96 & \\
\hline Total & & 300 & & 230 & & 233 & & 260 & & 252 \\
\hline
\end{tabular}

Source: Calculated values from the Annual Report of respective banks (2005-06 to 2014-15)

Table 7 reveals the year wise growth rate of Advances in India of selected PSBs. Growth rates of selected PSBs have shown the fluctuating and decreasing trend over the period from 2005-2014. It is found that average growth rate of BOB has highest and CB has lowest when compared to other banks. In order to ascertain statistical significant difference in the growth rate of advances in Indian sector of among the selected PSBs, on the basis of $\mathrm{H}$ test (KRUSKAL-WALLIS) the 'W' value has been calculate

$$
\begin{aligned}
& \boldsymbol{W}=\frac{\mathbf{1 2}}{\mathbf{5 0}(\mathbf{5 1})}\left|\frac{\mathbf{3 0 0}^{2}}{\mathbf{1 0}}+\frac{\mathbf{2 3 0}^{2}}{\mathbf{1 0}}+\frac{\mathbf{2 3 3}^{2}}{\mathbf{1 0}}+\frac{\mathbf{2 6 0}^{2}}{\mathbf{1 0}}+\frac{\mathbf{2 5 2}^{2}}{\mathbf{1 0}}\right|-\mathbf{3}(\mathbf{5 1}) \\
& W=\frac{12}{2550}(9000+5290+5428.9+6760+6350.4)-153 \\
& W=1.49
\end{aligned}
$$

\begin{tabular}{|c|c|c|c|c|c|c|c|c|c|c|}
\hline \multirow[t]{2}{*}{ Year } & \multicolumn{2}{|c|}{$\mathrm{BOB}$} & \multicolumn{2}{|c|}{ CB } & \multicolumn{2}{|c|}{ PNB } & \multicolumn{2}{|c|}{ BOI } & \multicolumn{2}{|l|}{ CBI } \\
\hline & Growth & Rank & Growth & Rank & Growth & Rank & Growth & Rank & Growth & Rank \\
\hline $2005-06$ & 23.43 & 14 & 1.25 & 4 & -29.94 & 1 & -4.95 & 2 & 0 & 3 \\
\hline $2006-07$ & 41.47 & 28 & 33 & 21 & 184.63 & 38 & 35.99 & 23 & 0 & 3 \\
\hline $2007-08$ & 35.7 & 22 & 89.7 & 37 & 9515.62 & 41 & 38.32 & 26 & 0 & 3 \\
\hline 2008-09 & 56.33 & 33 & 231.17 & 40 & 14.83 & 8 & 25.44 & 16 & 0 & 3 \\
\hline $2009-10$ & 25.04 & 15 & 200 & 39 & 82.31 & 35 & 22.7 & 13 & 0 & 3 \\
\hline 2010-11 & 36.59 & 24 & 51.48 & 32 & 85.04 & 36 & 41.39 & 27 & 0 & 3 \\
\hline 2011-12 & 43.92 & 29 & 4 & 5 & 68.6 & 34 & 44.13 & 30 & 0 & 3 \\
\hline $2012-13$ & 21.79 & 12 & 36.78 & 25 & 47.36 & 31 & 20.44 & 11 & 0 & 3 \\
\hline 2013-14 & 20.16 & 10 & 27.85 & 19 & 26.26 & 17 & 26.27 & 18 & 0 & 3 \\
\hline 2014-15 & 9.1 & 7 & 18.04 & 9 & 29.55 & 20 & 9.02 & 6 & 0 & 3 \\
\hline Average & 31.35 & & 69.33 & & 1002.42 & & 25.87 & & 0 & \\
\hline Total & & 194 & & 231 & & 261 & & 172 & & 30 \\
\hline
\end{tabular}

COMPARISION OF ADVANCE IN OUT SIDE INDIA OF SELECTED PUBLIC SECTOR BANKS

TABLE-8 Ranking of Growth Rates of Advance in Out Side India of Selected Public Selected Sector Bank

Source: Calculated values from the Annual Report of respective banks (2005-06 to 2014-15)

Table 8 illustrates year wise the growth rate of Advances in outside India of selected PSBs. Growth rates of Advances in outside India of selected bank have shown the fluctuating trend over the period of study. CBI has not made any 
investments outside India during the study period. It is found that average growth rate of PNB has highest and BOI has lowest when compared to other banks except the CBI. In order to ascertain statistical significant difference in the growth rate of advances in outside India of among the selected PSBs, on the basis of $\mathrm{H}$ test (KRUSKAL-WALLIS) the 'W' value has been calculated as:

$$
\begin{gathered}
\boldsymbol{W}=\frac{\mathbf{1 2}}{\mathbf{5 0}(\mathbf{5 1})}\left|\frac{\mathbf{1 9 4}^{2}}{\mathbf{1 0}}+\frac{\mathbf{2 3 1}^{2}}{\mathbf{1 0}}+\frac{\mathbf{2 6 1}^{2}}{\mathbf{1 0}}+\frac{\mathbf{1 7 2}^{2}}{\mathbf{1 0}}+\frac{\mathbf{3 0}^{2}}{\mathbf{1 0}}\right|-\mathbf{3}(\mathbf{5 1}) \\
W=\frac{12}{2550}(3763.6+5336.1+6812.1+2958.4+90)-153 \\
W=-63.77
\end{gathered}
$$

\section{FINDINGS OF THE STUDY}

The result of Kruskal- Wallis Test has been summarized below.

\begin{tabular}{|l|c|l|}
\hline & Table value at 5\%(9.488) & \\
\hline Variables & Calculated Value & Result \\
\hline Demand Deposits & 7.47 & Accepted \\
Saving Bank Deposits & 4.445 & Accepted \\
Term Deposits & 3.631 & Accepted \\
Total Deposits & 4.753 & Accepted \\
Priority Sector Advances & 1.875 & Accepted \\
Public Sector Advances & 0.018 & Accepted \\
Advances in India & 1.49 & Accepted \\
Advances outside India & -63.77 & Accepted \\
\hline
\end{tabular}

Source: Compiled from Annual Reports

The kruskal-Wallis clearly indicates that all variables under the study have been significant. Some banks in the group did not perform any activity in this segment and therefore it is suggested that these banks have take adequate steps to increase its incomes by increasing advances.

\section{CONCLUSION}

The study concludes that there is no significant difference among the demand deposits, saving bank deposits, term deposits, total deposits, priority sector advances, public sector advances and advances in India and outside India of various PSBs in India, 5 per cent significance levels. All selected banks have shown a fluctuating and decreasing growth rates over the selected period of study has not shown a good trend in the competitive and core sector. Therefore, it is suggested that all banks have to pay proper attention to manage their growth rates of deposits and advances, which may lead to a robust growth in banking business industry for banks and to same may sustain for long time survival. It has been observed that the advances outside India by these banks, PNB has highest growth rate of 1002.42 percent. On the other hand, CBI has zero growth rates by not lending any advances outside India for the last ten years under the study. Therefore it is suggested that the 
$\mathrm{CBI}$ has to take initiative to generate income by lending money to outside India also. Further, the growth rate of demand deposit in which $\mathrm{BOB}$ and $\mathrm{CB}$ has highest growth rate when compared to other PSBs and therefore it is suggested that these bank have to take precaution to curb dependency on deposits.

\section{REFERENCES}

\section{Journal Article:}

1. Anbalagan, M. \& Selvkumar, D. (2014), “Analysis of Deposits and Advances of Selected Private sector Commercial banks", International Journal of Management and Social science Research, 3, pp. 1016.

2. dhanabhakyam, M. \& Kavitha, M. (2012) "Financial Performance of Selected Public Sector Banks in India”; International Journal of Multidisciplinary Research, 2(1), pp 255-269.

3. Goel, C. \& Rekhi, C. B. (2013) "A Comparative Study on the Performance of Selected Public Sector and Private Sector Banks in India”; Journal of Business Management \& Social Science Research, 2(7), pp 46-56.

4. Jha, D. \& Sarangi, D. (2011) "Performance of New Generation Banks in India: A Comparative Study", International Journal of Research in Commerce and Management, 2, pp85-89.

5. Kaur, A. (2012) “An Empirical Study on the Performance Evaluation of Public Sector Banks in India” ; International Journal of Marketing, Financial Services and Management Research, 1(11),pp 117-131.

6. Nishi, D. (2012) "Deposits and advances: A Comparative Analysis of Indian Commercial Banks”, Asian Journal of Research in Banking and Finance, 2(9), pp 59-71.

\section{Books:}

1. Muraleedharan, D. (2009) "Modern Banking: Thory and Practic"; PHI Learning PVT.Ltd.

\section{Websites:}

1. Http://www.ibef.org/industry/banking-india.aspx 